\title{
TEKNIK PEMBESARAN UDANG VANAME (Litopenaeus vannamei) PADA TAMBAK PENDAMPINGAN PT CENTRAL PROTEINA PRIMA TbK DI DESA RANDUTATAH, KECAMATAN PAITON, PROBOLINGGO, JAWA TIMUR
}

\section{Enlargement Technique of Vannamei Shrimp (Litopenaeus vannamei) on Mentoring Pond of PT Central Proteina Prima Tbk in Randutatah Village, Paiton, Probolinggo, East Java}

\author{
Muhammad Ghufron ${ }^{1}$, Mirni Lamid ${ }^{2}$, Putri Desi Wulan Sari ${ }^{2}$ dan Hari Suprapto ${ }^{2}$. \\ ${ }^{1}$ Program Studi Budidaya Perairan, Fakultas Perikanan dan Kelautan, Universitas Airlangga, Surabaya \\ ${ }^{2}$ Departemen Manajemen Kesehatan Ikan dan Budidaya Perairan, Fakultas Perikanan dan Kelautan, Universitas \\ Airlangga, Surabaya \\ *muhammad.ghufron-2014@fpk.unair.ac.id
}

\begin{abstract}
Abstrak
Udang vaname merupakan salah satu komoditas perikanan yang memiliki nilai ekonomi tinggi. Produktivitas dari komoditas ini dapat mencapai lebih dari $13.600 \mathrm{~kg} / \mathrm{ha}$ dengan permintaan yang selalu meningkat di kalangan masyarakat. Praktek Kerja Lapang (PKL) ini bertujuan untuk memperoleh pengetahuan dan pengalaman mengenai teknik pembesaran udang vaname. Praktek Kerja Lapang dilaksanakan di tambak pendampingan PT Central Proteina Prima Tbk pada tanggal 20 Januari sampai 21 Februari 2017. Lokasi tambak tersebut yaitu di Desa Randutatah, Kecamatan Paiton, Probolinggo, Jawa Timur. Metode kerja yang digunakan yaitu metode deskriptif. Metode tersebut meliputi wawancara, pengamatan, dan partisipasi aktif selama proses kegiatan pembesaran udang vaname. Data yang terkumpul terdiri atas data primer dan sekunder. Data primer berupa pertumbuhan udang vaname, kualitas air, serta pemberian pakan selama proses budidaya. Sedangkan data sekunder berupa hasil studi data literatur mengenai teknis pembesaran udang vaname. Selain itu, data sekunder juga bisa diambil berdasarkan dokumen pendukung mengenai sejarah berdirinya, struktur organisasi, sarana dan prasarana budidaya. Kegiatan pembesaran udang vaname (Litopenaeus vannamei) selama pelaksanaan Praktek Kerja Lapang meliputi persiapan tambak, penebaran benur, manajemen pakan dan kualitas air, pengendalian hama dan penyakit, pemanenan, dan pemasaran.
\end{abstract}

Kata kunci: Udang Vaname, Tambak, Pakan, Kualitas Air, Hama dan Penyakit

\begin{abstract}
Vannamei Shrimp (Litopenaeus vannamei) is one of the fisheries commodities which have a high economic value. Productivity of this commodity can reach over $13.600 \mathrm{~kg} / \mathrm{ha}$. The objective of this internship is to acquire knowledge and experience about enlargement technique of vannamei shrimp. The intersnship was held in mentoring pond of PT Central Proteina Prima Tbk on January 20 until February 21, 2017. The location of that pond was in Randutatah Village, Kecamatan Paiton, Probolinggo, Jawa Timur. The method used during the internship was the descriptive method. The descriptive method included an interview, an observation, and an active participation during the enlargement process of vannamei shrimp. The collected data from that method were the primary data and the secondary data. The primary data involved the shrimp growth, water quality, and feeding management during the aquaculture process. The secondary data involved the result of some literature studies about the technique of shrimp enlargement. The secondary data were also collected from the support document about the company history, organization structure, and facilities in shrimp aquaculture. The activity of vannamei shrimp rearing culture during the internship included covering pond preparation, shrimp stocking, feed and water quality management, pest and disease control, harvesting, and marketing aspect.
\end{abstract}

Keywords: Vannamei Shrimp, Pond, Feed, Water Quality, Pest and Disease

\section{PENDAHULUAN}

Udang merupakan salah satu komoditas ekspor dari sub sektor perikanan yang memiliki nilai ekonomi tinggi. Salah satu jenis udang yang permintaannya cukup tinggi baik di dalam 
maupun luar negeri yaitu udang vaname (Litopenaeus vannamei). Kementerian Kelautan dan Perikanan menyatakan perkiraan kebutuhan udang vaname di Jepang 420.000 ton/tahun, Amerika Serikat sebesar 560.000-570.000 ton/tahun dan Uni Eropa 230.000-240.000 ton/tahun. Dijelaskan oleh Direktorat Jendral Perikanan Budidaya pada tahun 2013, Indonesia baru memproduksi udang vaname sebesar 500.000 ton/tahun. Hasil tersebut belum mencukupi semua kebutuhan pasar dunia, maka pada tahun 2014 target produksi udang vaname ditingkatkan menjadi 699.000 ton/tahun agar dapat memenuhi kebutuhan pasar tersebut (Erlando et al., 2015).

Di Indonesia, keberadaan udang vaname sudah bukan hal yang asing lagi karena keunggulan-keunggulan yang dimiliki oleh udang introduksi tersebut telah berhasil merebut simpati para pembudidaya, sehingga sejauh ini keberadaannya dinilai dapat menggantikan spesies udang windu (Penaeus monodon) sebagai alternatif kegiatan diversifikasi usaha yang positif. Udang vaname secara resmi diperkenalkan pada masyarakat pembudidaya pada tahun 2001 setelah menurunnya produksi udang windu karena berbagai masalah yang dihadapi dalam proses produksi, baik masalah teknis maupun non teknis (Subyakto et al., 2008).

Berdasarkan penelitian Boyd dan Jason (2002), produktivitas udang vaname dapat mencapai lebih dari $13.600 \mathrm{~kg} / \mathrm{ha}$. Komoditas ini mempunyai beberapa keunggulan dibandingkan dengan spesies udang lainnya, antara lain lebih mampu beradaptasi terhadap kepadatan tinggi, tahan terhadap serangan penyakit, dapat hidup pada kisaran salinitas 5 hingga 30 ppt, serta mempunyai tingkat survival rate (SR) atau kelulushidupan dan konversi pakan yang tinggi.

Dalam proses budidaya udang vaname, dibagi menjadi 3 sektor kegiatan, yakni pembenihan, pendederan, dan pembesaran. Kegiatan pembesaran udang vaname sendiri meliputi persiapan tambak, pemilihan dan penebaran benur, pemeliharaan kualitas air, pengelolaan pakan dan pengendalian penyakit, hingga panen. Oleh sebab itu, agar dapat lebih memahami serangkaian kegiatan dari salah satu sektor tersebut, diperlukan pelaksanaan praktek kerja lapang mengenai teknik pembesaran udang vaname di tambak pendampingan PT Central Proteina Prima Tbk.

\section{METODOLOGI}

\section{Waktu dan Tempat}

Kegiatan Praktek Kerja Lapang ini dilaksanakan di tambak pendampingan PT Central Proteina Prima Tbk yang terletak di Desa Randutatah, Kecamatan Paiton, Probolinggo, Jawa Timur. Kegiatan dilaksanakan pada tanggal 20 Januari-21 Februari 2017.

\section{Metode Penelitian}

Metode kerja yang digunakan dalam pelaksanaan Praktek Kerja Lapang ini adalah metode deskriptif. Sedangkan pengambilan data dilakukan dengan proses observasi atau pengamatan langsung. Disamping itu, dapat dilakukan juga melalui wawancara dengan pihak terkait dan partisipasi aktif selama proses pelaksanaan budidaya. Data yang terkumpul meliputi persiapan tambak, penebaran benur, manajemen pakan dan kualitas air, pengendalian hama dan penyakit, pemanenan, dan pemasaran.

\section{HASIL DAN PEMBAHASAN Persiapan Tambak}

Sebelum dilakukan penebaran, tambak beton yang merupakan wadah pembesaran udang vaname dicuci dengan menggunakan air tawar. Pencucian tersebut dimaksudkan untuk membersihkan kotoran yang menempel pada dasar dan dinding tambak yang berpotensi membawa hama dan penyakit selama proses budidaya. Tambak yang sudah bersih tersebut kemudian dikeringkan di bawah sinar matahari dengan tujuan untuk membunuh sisa-sisa organisme dan menguapkan bahan organik beracun yang ada di dasar 
tambak. Selama proses pengeringan, pemasangan CPD (Crab Protecting Device) dapat dilakukan untuk mencegah masuknya hewan-hewan yang merupakan hama dan agen pembawa penyakit, terutama kepiting.

Setelah itu, tambak diisi dengan air yang berasal dari sumur bor air asin sampai ketinggian $120 \mathrm{~cm}$. Sebelum pengisian air, pengaturan lokasi kincir dapat dilakukan. Upaya yang dilakukan untuk membasmi crustacea yang terdapat dalam air yaitu dengan penggunaan krustasida yang mengandung dichlorvos. Erdogan et al. (2007) menyatakan bahwa dichlorvos (2,2-dichlorovinyl dimethyl phosphate; DDVP) dapat membunuh crustacea dengan cara menghambat aktivitas enzim asetilkolinesterase (AChE). Krustasida ini diaplikasikan dengan cara langsung ditebar ke tambak pada pagi hari dengan konsentrasi 1 ppm. Kincir air dapat digunakan agar krustasida dapat tersebar secara merata.

Pada hari berikutnya, cupri sulfat dapat diberikan sebagai algasida. Cupri sulfat dapat menekan pertumbuhan alga dengan cara menghambat proses fotosintesis dan fosforilasi oksidatif pada rantai transportasi elektron (Pradeep et al., 2015). Kadar cupri sulfat tergantung pada nilai alkalinitas air tambak. Semakin tinggi alkalinitas, maka semakin tinggi pula dosis cupri sulfat yang diberikan. Setelah 24 jam, perlakuan selanjutnya yaitu pemberian kaporit dengan dosis $30 \mathrm{ppm}$. Tujuan dari pemberian kaporit adalah sebagai upaya sanitasi air yang dapat membunuh bakteri dan mikroorganisme lain yang merupakan bahan pencemar. Disamping itu, kaporit juga dapat mengoksidasi zat besi yang apabila konsentrasinya terlalu tinggi dapat membahayakan kelangsungan hidup udang vaname (Azzahrah dan Andi, 2014).

Selain proses sterilisasi, penumbuhan mikroorganisme dan plankton juga perlu dilakukan dalam kegiatan persiapan tambak sebelum dilakukan penebaran udang vaname. Kegiatan ini dapat dilaku- kan tiga hari setelah aplikasi pemberian kaporit. Bahan yang digunakan sebagai nutrisi mikroorganisme dalam perairan yaitu dedak sebanyak $3 \mathrm{ppm}$, fermipan (mengandung Saccharomyces cerevisae dan antioksidan) $15 \mathrm{gr} / \mathrm{kg}$ dedak, dan air. Perbandingan air dan dedak yang digunakan yaitu 1:1. Setelah dicampur hingga merata, ketiga bahan tersebut disimpan dalam ember tertutup selama 48 jam agar dapat terjadi proses fermentasi. Sebelum ditebar ke tambak, hasil fermentasi tersebut diperas agar diperoleh airnya saja, sedangkan substratnya dibuang. Penebaran hasil fermentasi tersebut dapat dilakukan pada pagi hari dan diikuti dengan pemberian probiotik pada satu jam selanjutnya. Probiotik tersebut merupakan starter dari beberapa species bakteri, seperti Bacillus sp., Pseudomonas sp., Nitrosomonas sp., Aerobacter sp., dan Nitrobacter sp.

\section{Penebaran Benur}

Ukuran udang vaname yang siap ditebar ke tambak yaitu $\mathrm{PL}_{10}$. Sebelum benur dipindahkan dari dalam kantong plastik ke tambak, benur perlu diaklimatisasi terlebih dahulu. Andriyanto (2013) menyatakan bahwa aklimatisasi benur dimaksudkan untuk mencegah tingginya tingkat kematian (mortalitas) benur pada saat dan setelah penebaran. Aklimatisasi terhadap suhu dapat dilakukan dengan cara merendam kantong plastik yang telah berisi benur dalam keadaan tertutup hingga muncul adanya uap di dalam kantong plastik tersebut. Hal itu menunjukkan bahwa suhu di dalam kantong plastik sudah sama dengan suhu air tambak.

Setelah itu, aklimatisasi terhadap salinitas dapat dilakukan dengan cara memasukkan air tambak sedikit demi sedikit ke dalam kantong plastik yang telah berisi benur tersebut hingga penuh dan benur dapat keluar dengan sendirinya. Kegiatan penebaran benur dapat dilakukan pada pagi atau sore hari bersamaan dengan penebaran Artemia sebagai pakan alami benur tersebut. Lokasi penebaran benur 
berada di titik yang berarus lemah agar benur tidak stress, sedangkan lokasi penebaran Artemia berada di dekat kincir agar Artemia tersebut dapat tersebar secara merata.

\section{Manajemen Pakan}

Pakan yang diberikan selama proses pembesaran udang vaname yaitu pakan berupa crumble/remahan. Hal ini disebabkan karena ukuran bukaan mulut udang vaname yang masih relatif kecil. Pada awal bulan pertama, pemberian pakan dilakukan dengan menggunakan metode blind feeding. Metode blind feeding merupakan metode menentukan dosis pakan udang dengan memperkirakan dosis yang diperlukan tanpa melakukan sampling berat udang. Jumlah pakan awal yang diberikan setiap 100.000 ekor benur yaitu sebanyak tiga kilogram. Pada umur 1-10 hari, penambahan pakan perharinya sebanyak 200 gram, 11-20 hari sebanyak 400 gram, dan 21-30 hari sebanyak 600 gram. Setelah itu, pada bulan selanjutnya pemberian pakan disesuaikan dengan biomassa udang dan dikontrol dengan menggunakan indikator skor cek anco. Aplikasi pakan tambahan juga diterapkan pada pemeliharaan udang vaname. Pakan tambahan yang dimaksud, antara lain vitamin $\mathrm{C}$, omega protein, dan probiotik.

Sampling dilakukan satu minggu sekali untuk mengetahui berat rata-rata dan biomassa udang vaname sehingga jumlah pakan harian udang vaname dapat ditentukan. Selain itu, hasil sampling juga dapat digunakan untuk memantau laju pertumbuhan berat dan menduga rasio konversi pakan (FCR) sementara udang vaname. Berikut rumus perhitungan laju pertumbuhan berat (Jaya dkk., 2013) dan FCR (Ridlo dan Subagiyo, 2013) pada pemeliharaan udang vaname.

\section{Manajemen Kualitas Air}

Kualitas air memegang peranan penting dalam kegiatan budidaya karena dapat mempengaruhi kelangsungan hidup dan kecepatan pertumbuhan udang vaname. Oleh sebab itu, kualitas air perlu diperhatikan secara intensif. Menurut periodenya, pemeriksaan kualitas air terbagi menjadi dua, yaitu pemeriksaan setiap hari dan setiap minggu. Parameter kualitas air yang diukur setiap hari diantaranya suhu, kecerahan, salinitas, dan $\mathrm{pH}$. Pengukuran parameter-parameter tersebut dilakukan pada pagi dan sore hari. Sedangkan parameter yang diukur setiap minggu yaitu kesadahan, alkalinitas, nitrit, TAN (Total Ammonia Nitrogen), TOM (Total Organic Matter), serta jumlah plankton dan bakteri.

Suhu air yang didapat dari pengukuran di tambak pembesaran udang vaname adalah berkisar pada $28-31^{\circ} \mathrm{C}$. Suhu air tersebut masih merupakan suhu yang optimal bagi kehidupan udang. Hal ini sesuai dengan pernyataan Kharisma dan Manan (2012) bahwa suhu optimal yang diperlukan oleh udang vaname yaitu berkisar antara $28-32{ }^{\circ} \mathrm{C}$. Pada kisaran suhu tersebut proses metabolisme dapat berjalan dengan baik sehingga kelangsungan hidup dan pertumbuhan udang diharapkan dapat optimal.

Kecerahan pada tambak udang vaname berkisar antara $15-35 \mathrm{~cm}$. Menurut Malik (2014), kecerahan optimal air tambak yaitu sekitar 20-40 cm. Oleh sebab itu, apabila kecerahan air tambak di bawah $20 \mathrm{~cm}$, maka upaya yang dapat dilakukan yaitu dengan melakukan pengenceran terhadap air tambak hingga didapatkan kecerahan yang optimal untuk menunjang kehidupan udang budidaya. Rahmawati dkk., (2014) menyatakan bahwa faktorfaktor yang dapat mempengaruhi nilai kecerahan yaitu keadaan cuaca, padatan tersuspensi, waktu pengukuran, dan ketelitian orang yang melakukan pengukuran.

Nilai salinitas air tambak yang didapat selama kegiatan PKL yaitu 9-17 ppt. Salinitas air sangat erat hubungannya dengan proses osmoregulasi yang terdapat pada organisme perairan. Udang vaname termasuk organisme euryhaline yang mampu beradaptasi pada kisaran salinitas yang sangat luas, yakni 1-40 ppt. Namun, 
untuk mendapatkan pertumbuhan yang optimal, udang vaname membutuhkan salinitas 15-25 ppt (Malik, 2014). Oleh sebab itu, salinitas air tambak perlu dinaikkan agar tidak berada di bawah kisaran optimal selama proses budidaya. Upaya yang dapat dilakukan yaitu dengan menambah air bersalinitas tertentu yang sudah disterilisasi.

Kadar pH yang diukur selama kegiatan PKL berada pada kisaran $\mathrm{pH}$ yang optimal, yakni 7,7-8,4. Menurut Malik (2014), pH air tambak yang ideal untuk pembesaran udang vaname yaitu 7,5-8,5. Pada umumnya, $\mathrm{pH}$ air tambak pada sore hari lebih tinggi daripada pagi hari. Hal ini disebabkan pada sore hari telah terjadi penyerapan karbondioksida $\left(\mathrm{CO}_{2}\right)$ oleh fitoplankton melalui proses fotosintesis. Sedangkan pada pagi hari kadar $\mathrm{CO}_{2}$ hasil respirasi udang vaname dan organisme lain dalam perairan cukup tinggi.

Alkalinitas merupakan gambaran dari kapasitas air yang dapat menetralkan asam atau kuantitas anion air untuk menetralkan kation hidrogen serta sebagai kapasitas penyangga terhadap perubahan pH perairan (Djokosetiyanto dkk., 2005). Selama kegiatan PKL dilaksanakan, nilai alkalinitas air tambak yaitu berkisar 137,31-160 ppm. Menurut Kilawati dan Yunita (2014), nilai alkalinitas yang optimal untuk pemeliharaan udang vaname yaitu 100-150 ppm. Oleh sebab itu, pada tambak ini dilakukan pengenceran agar nilai alkalinitas tidak di atas $150 \mathrm{ppm}$.

Pada kegiatan budidaya, semakin bertambahnya umur udang, maka jumlah pemberian pakan semakin meningkat pula. Peningkatan jumlah pakan ini dapat memicu peningkatan bahan organik dan senyawa toksik, seperti nitrit $\left(\mathrm{NO}_{2}\right)$ dan amonia $\left(\mathrm{NH}_{3}\right)$. Selain berasal dari sisa pakan yang tidak terkonsumsi, kedua senyawa tersebut juga dapat berasal dari feses hasil ekskresi udang (Wulandari dkk., 2015). Menurut Kilawati dan Yunita (2014), kadar $\mathrm{NO}_{2}$ dan $\mathrm{NH}_{3}$ yang optimal untuk pertumbuhan udang vaname yaitu di bawah 0,01 ppm, sedangkan batas toleransi untuk $\mathrm{NO}_{2}$ berkisar antara 0,01-0,1 ppm dan $\mathrm{NH}_{3}$ sekitar 0,01-0,2 ppm. Kadar $\mathrm{NO}_{2}$ dan $\mathrm{NH}_{3}$ pada tambak budidaya berada di luar nilai optimal, yaitu berturutturut dapat mencapai 0,968 ppm dan 0,37 ppm. Upaya yang dapat dilakukan untuk mengatasi masalah tersebut yaitu dengan aplikasi probiotik yang mengandung bakteri nitrifikasi.

Bahan Organik Total (TOM) menggambarkan kandungan bahan organik total suatu perairan yang terdiri atas bahan organik terlarut, tersuspensi dan koloid. Bahan organik yang berlebihan dapat menyebabkan terjadinya perubahan kualitas air tambak dan mempengaruhi kehidupan biota tambak, terutama udang budidaya. Kandungan bahan organik yang meningkat akan mengakibatkan meningkatnya unsur hara, menurunnya $\mathrm{pH}$ dan oksigen terlarut, serta peningkatan aktifitas biologi (Suwoyo, 2011). Nilai TOM pada tambak berkisar antara 103,65115,57. Kilawati dan Yunita (2014) menyatakan bahwa kamdungan TOM yang layak untuk kehidupan udang yaitu di bawah 55 ppm. oleh sebab itu, upaya yang dapat dilakukan untuk mengurangi kandungan TOM pada tambak yaitu dengan melakukan pergantian air dan penyiponan secara rutin.

Keberadaan plankton di perairan dapat dijadikan sebagai indikator biologi untuk mengevaluasi kualitas dan tingkat kesuburan suatu perairan. Plankton terbagi menjadi dua golongan, yaitu fitoplankton dan zooplankton. Plankton merupakan pakan alami bagi organisme perairan. Selain sebagai pakan alami, fitoplankton juga dapat menghasilkan oksigen terlarut melalui proses fotosintesis (Makmur, 2011).

Kepadatan bakteri Vibrio dan total bakteri secara umum berturut-turut yaitu 170-880 CFU/ml dan 7000-118000 $\mathrm{CFU} / \mathrm{ml}$. Angka tersebut masih dapat ditolerir dalam kegiatan budidaya udang vaname. Menurut Kharisma dan Manan (2012), ambang batas maksimal kebera- 
daan bakteri Vibrio sp. dalam air adalah $10^{4} \mathrm{CFU} / \mathrm{ml}$, sedangkan batas maksimal bakteri umum di perairan adalah $10^{6}$ $\mathrm{CFU} / \mathrm{ml}$. Jika ambang batas ini dilampaui maka kematian massal udang budidaya dalam tambak dapat terjadi.

\section{Hama dan Penyakit}

Pencegahan masuknya hama dan penyakit udang dilakukan sejak tahap persiapan tambak. Salah satu langkah yang dilakukan yaitu dengan memasang CPD (Crab Protecting Device) di bagian tepi tambak. Hal ini dimaksudkan agar kepiting tidak dapat masuk ke perairan budidaya. Selain sebagai hama yang dapat menjadi kompetitor udang dalam hal pakan, oksigen terlarut dan ruang gerak, kepiting juga dapat sebagai agen pembawa suatu penyakit, misalnya WSSV. Selain itu, upaya yang dilakukan untuk mencegah adanya hama dan penyakit yaitu dengan pemberian krustasida, cupri sulfat, kaporit dan probiotik yang telah dijelaskan pada subbab persiapan tambak.

\section{Panen}

Udang dapat dipanen setelah memasuki ukuran pasar (100-30 individu/ $\mathrm{kg}$ ). Untuk mendapatkan kualitas udang yang baik, sebelum panen dapat dilakukan penambahan dolomit untuk mengeraskan kulit udang dengan dosis 6-7 ppm. Selain dolomit juga dapat menggunakan kapur $\mathrm{Ca}(\mathrm{OH})_{2}$ dengan dosis 5-20 ppm sehari sebelum panen untuk menaikkan $\mathrm{pH}$ air hingga 9 agar udang tidak molting (Malik, 2014).

\section{Pemasaran}

Para petambak biasanya sudah berkomunikasi dengan calon pembeli sebelum dilakukan kegiatan pemanenan. Setelah mencapai kesepakatan harga, para pembeli akan berdatangan ke lokasi ketika proses pemanenan dilakukan dengan membawa styrofoam/cool box sendiri. Para pembeli udang vaname tersebut biasanya berasal dari Surabaya, Sidoarjo, dan Banyuwangi.

\section{Hambatan dan Kemungkinan Pengem- bangan Usaha}

Salah satu hambatan yang terdapat pada kegiatan pembesaran udang vaname di tambak pendampingan CP Prima ini yaitu salinitas air dari sumur bor tidak konstan, sehingga pada waktu pengisian air perlu dilakukan pengukuran terlebih dahulu agar kebutuhan air asin dan air tawar dapat diperhitungkan. Selain itu, hujan yang terlalu deras dapat menyebabkan salinitas air menurun drastis, sehingga petambak harus mempunyai persediaan air asin yang siap untuk dimasukkan ke petak-petak yang ada.

Di sisi lain, pada daerah sekitar lokasi tambak ini memiliki peluang pengembangan usaha yang sangat luas. Hal ini didukung oleh masih banyaknya lahan kosong yang tidak terpakai dan dapat dimanfaatkan sebagai lahan budidaya udang vaname. Saat ini pemilik tambak sudah membeli beberapa lahan-lahan di sekitar lokasi untuk memperluas area usaha yang ada. Tujuan dari pengembangan usaha yang dilakukan yaitu untuk memperbanyak pemasukan dan mengoptimalkan fungsi lahan-lahan di sekitar lokasi budidaya.

\section{KESIMPULAN DAN SARAN Kesimpulan}

Berdasarkan hasil Praktek Kerja Lapang (PKL) tentang Teknik Pembesaran Udang Vaname (Litopenaeus vannamei) pada Tambak Pendampingan PT Central Proteinaprima Tbk di Desa Randutatah, Kecamatan Paiton, Probolinggo, Jawa Timur dapat ditarik kesimpulan bahwa pada pembesaran udang vaname meliputi kegiatan persiapan tambak, penebaran benur, manajemen pakan dan kualitas air, pengendalian hama dan penyakit, pemanenan, dan pemasaran. Hambatan yang terdapat pada kegiatan ini yaitu salinitas air sumber yang tidak konstan dan hujan yang terlalu deras. Sedangkan peluang pengembangan usaha di area lokasi budidaya sangat luas karena masih banyak lahan yang potensial untuk dijadikan tambak. 


\section{Saran}

Berdasarkan beberapa hambatan yang ditemui selama Praktek Kerja Lapang, sebaiknya pada kolam busmetik diterapkan biosecurity agar hama tidak mudah masuk dan pensterilan alat pengukuran kualitas air agar tidak terjadi kontaminasi silang penyakit antara satu kolam dengan kolam yang lain.

\section{DAFTAR PUSTAKA}

Andriyanto, F., A. Efani dan H. Riniwati. 2013. Analisis Faktor-Faktor Produksi Usaha Pembesaran Udang Vanname (Litopenaeus vannamei) di Kecamatan Paciran Kabupaten Lamongan Jawa Timur ; Pendekatan Fungsi Cobb-Douglass. Jurnal ECSOFiM, 1 (1) : 82-96.

Azzahrah, F. dan A. Susilawaty. 2014. Efektivitas Pembubuhan Kaporit dalam Menurunkan Kadar Zat Besi (Fe) pada Air Sumur Gali Tahun 2013. Jurnal Kesehatan, 7 (1) : 322-331.

Boyd, C.E. and Jason C. 2002. Evaluation of Belize Aquaculture, Ltd: A Superintensive Shrimp Aquaculture System". Report prepared under the World Bank, NACA, WWF and FAO Consortium Program on Shrimp Farming and the Environment. Work in Progress for Public Discussion. Published by the Consortium. 17 hal.

Djokosetiyanto, D., R. K. Dongoran dan E. Supriyono. 2005. Pengaruh Alkalinitas Terhadap Kelangsungan Hidup dan Pertumbuhan Larva Ikan Patin Siam (Pangasius sp.). Jurnal Akuakultur Indonesia, 4 (2) : 53-56.

Erdogan, O., M. Atamanalp, T. Sisman, E. Aksakal and G. Alak. 2007. Effects of 2,2-Dichlorovinyl Dimethyl Phosphate (DDVP) on Hsp70 Gene Expression in Rainbow Trout. The Israeli Journal of Aquaculture, 59 (4) : 230-234.
Erlando, G., Rusliadi dan Mulyadi. 2015. Increasing Calcium Oxide $(\mathrm{CaO})$ to Accelerate Moulting and Survival Rate Vannamei Shrimp (Litopenaeus vannamei). Aquaculture Technology Laboratory. Faculty of Fisheries and Marine Sciences. University of Riau. 7 hal.

Jaya, B., F. Agustriani, dan Isnaini. 2013. Laju Pertumbuhan dan Tingkat Kelangsungan Hidup Benih Kakap Putih (Lates calcarifer, Bloch) dengan Pemberian Pakan yang Berbeda. Maspari Journal, 5 (1) : 56-63.

Kharisma, A. dan A. Manan. 2012. Kelimpahan Bakteri Vibrio sp. pada Air Pembesaran Udang Vannamei (Litopenaeus vannamei) Sebagai Deteksi Dini Serangan Penyakit Vibriosis. Jurnal Ilmiah Perikanan dan Kelautan, 4 (2) : 129-134.

Kilawati, Y. dan Y. Maimunah. 2014. Kualitas Lingkungan Tambak Intensif Litopenaeus vannamei dalam Kaitannya dengan Prevalensi Penyakit White Spot Syndrome Virus. Research Journal of Life Science, 2 (1) : 50-59.

Makmur, R. dan M. Fahrur. 2011. Hubungan Antara Kualitas Air dan Plankton di Tambak Kabupaten Tanjung Jabung Barat Provinsi Jambi. Prosiding Forum Inovasi Teknologi Akuakultur. Halaman 961-968.

Malik, I. 2014. Budidaya Udang Vannamei : Tambak Semi Intensif dengan Instalasi Pengolahan Air Limbah (IPAL). WWF-Indonesia. Jakarta. Halaman 3-30.

Nuhman. 2008. Pengaruh Prosentase Pemberian Pakan Terhadap Kelangsungan Hidup dan Laju Pertumbuhan Udang Vannamei (Litopenaeus vannamei). Berkala Ilmiah Perikanan, 3 (1) : 35-39.

Pradeep, V., S.W.V. Ginkel, S. Park, T. Igou, C. Yi, H. Fu, R. Johnston, T. 
Snell and Y. Chen. 2015. Use of Copper to Selectively Inhibit Brachionus calyciflorus (Predator) Growth in Chlorella kessleri (Prey) Mass Cultures for Algae Biodiesel Production. International Journal of Molecular Sciences, 16 : 2067420684.

Rahmawati, I., I.B. Hendrarto dan P.W. Purnomo. 2014. Fluktuasi Bahan Organik dan Sebaran Nutrien serta Kelimpahan Fitoplankton dan Klorofil-A di Muara Sungai Sayung Demak. Diponegoro Journal of Maquares, 3 (1) : 27-36.

Ridlo, A. dan Subagiyo. 2013. Pertumbuhan, Rasio Konversi Pakan dan Kelulushidupan Udang Litopenaeus vannamei yang Diberi Pakan dengan Suplementasi Prebiotik FOS (Fruktooligosakarida). Buletin Oseanografi Marina, 2 (4) : 1-8.

Subyakto, S., D. Sutende, M. Afandi dan Sofiati. 2008. Budidaya Udang Vannamei (Litopenaeus vannamei) Semiintensif dengan Metode Sirkulasi Tertutup untuk Menghindari Serangan Virus. Berkala Ilmiah Perikanan, 3 (1) : 1-7.

Suwoyo, H.S. 2011. Kajian Kualitas Air pada Budidaya Kerapu Macan (Epinephelus fuscoguttatus) Sistem Tumpang Sari di Areal Mangrove. Berkala Perikanan Terubuk, 39 (2) : 25-40. 